\title{
RE-THINKING THE STATE'S DUTY TO PROTECT AND UPHOLD THE RIGHT TO LIFE IN A CRIMINAL JUSTICE CONTEXT
}

\author{
Narnia Bohler-Muller
}

BJuris LLB LLM LLD

Professor of Law

Nelson Mandela Metropolitan University

Port Elizabeth

Jana Milne

LLB LLM

Public Prosecutor of the High Court, Port Elizabeth

\section{SUMMARY}

The central question posed in this contribution is whether the right to life has been employed by our courts as a workable constitutional concept in order to promote a quality of life - referred to herein as a "safe" life - lived in accord with the constitutional rights and values of human dignity, equal worth and freedom. A preliminary observation is that the South African judiciary is generally hesitant to interpret the right to life as the right to a certain "quality of life". This is due to the fact that the state's obligations regarding the entitlements that would enable such an existence are dealt with effectively by other rights already codified in the Constitution. In addition, the courts are traditionally wary of imposing duties on the state. Our courts have thus employed an interpretation of this right that is limited to the right not to be deprived of one's life in cases involving social policy issues. As such, the judiciary has failed to address the entitlement to a quality of life that would impose positive obligations on the state effectively. In order to explore more fully the ambit of the right to life, the authors turn to the Indian experience, which provides an excellent example of a more creative interpretation of this right. It is submitted that the Indian position could provide useful guidelines in advancing a more activist interpretation of the right to life in order to facilitate the effective application of this right in a criminal justice context.

\section{INTRODUCTION: THE CONSTITUTIONAL ROLE,} VALUE AND AMBIT OF THE RIGHT TO LIFE

"The right to life is, in one sense, antecedent to all the other rights in the Constitution. Without life in the sense of existence, it would not be possible to exercise rights or to be the bearer of them. But the right to life was included in the Constitution not simply to enshrine the right to existence. It is not life as mere organic matter that the Constitution cherishes, but the right to human 
life: the right to live as a human being, to be part of a broader community, to share in the experience of humanity. This concept of human life is at the centre of our constitutional values. The Constitution seeks to establish a society where the individual value of each member of the society is recognised and treasured. The right to life is central to such a society."

It is submitted that this statement from the case of $S v$ Makwanyane $^{2}$ provides an illustration of the way in which the constitutional right to life can be understood within the South African context. The central question posed in this contribution is whether this right - as an antecedent human right and the centre of all constitutional values - has been employed by our courts as a workable constitutional concept in order to promote the quality of life as envisaged in Makwanyane. This quality of life, referred to herein as a "safe" life, essentially entails an existence in accord with human dignity and equal worth, ${ }^{3}$ which enables all persons to enjoy a quality of life that goes beyond mere survival.

This question must be answered in light of section 2 of the Constitution, ${ }^{4}$ which establishes the supremacy of the Constitution; section 7(2) which requires the state to "respect, protect, promote and fulfill the rights in the Bill of Rights"; section 8(1) which provides that the Bill of Rights "binds the legislature, the executive, the judiciary and all organs of state"; section 165 (2), which requires that the courts must apply the Constitution "impartially and without fear, favour and prejudice" and section 237, which provides that "[a]II constitutional obligations must be performed diligently and without delay".

A preliminary observation is that the South African judiciary is generally hesitant to interpret the right to life as the right to a certain "quality of life". This is due to the fact that the state's obligations regarding the entitlements that would enable such an existence are dealt with effectively by other rights already codified in the Constitution, particularly socio-economic rights. In addition, the courts are traditionally wary of imposing duties on the state to enable a certain standard of living as they view this as falling within the domain of the legislature and executive. ${ }^{5}$ It is submitted that the rationale for this restrained approach rests upon the fact that a nudum right, ${ }^{6}$ phrased positively and in the affirmative without subsequent qualification, ${ }^{7}$ was entrenched in both the 1993 and 1996 Constitutions. ${ }^{8}$

\footnotetext{
S v Makwanyane 19956 BCLR (CC) par 326 (hereinafter "Makwanyane") (authors' own emphasis).

Supra.

Currie and De Waal The Bill of Rights Handbook 5ed (2006) 289-290.

Constitution of the Republic of South Africa, 1996 (hereinafter "the 1996 Constitution").

Currie and De Waal 290.

Van Wyk, Dugard, De Villiers and Davis Rights and Constitutionalism: The New South African Legal Order (1994) 220.

7 Fedler "15 Life" www.chr.up.ac.za/centre_publications/constitlaw/pdf/15-Life.pdf (accessed 2008-11-10) (hereinafter "Fedler.pdf 15-3").

8 S 9 of the 1993 Constitution provides that "Every person shall have the right to life" and s 11 of the 1996 Constitution provides that "Everyone has the right to life".
} 
In this regard, the following quote from Makwanyane is of particular significance:

"It is the responsibility of the Courts, and ultimately this Court, to develop fully the rights entrenched in the Constitution. But that will take time. Consequently, any minimum content which is attributed to a right may in subsequent cases be expanded and developed."

Despite recognising the importance of fully developing the right to life, our courts have subsequently employed an interpretation of this right that is limited to the right not to be deprived of one's life in cases involving social policy issues such as the death penalty. ${ }^{10}$ As such, our courts have failed to effectively address the entitlement to a quality of life that would impose positive obligations on the state. It is submitted that this restrained approach is facilitated by the fact that it is possible to deal with the state's duties regarding the quality of life of individuals and groups by referring to duties directly imposed by other rights. ${ }^{11}$ The primary examples of such rights being the right to freedom and security of the person - including freedom from all forms of public and private violence as contained in section 12(1)(c) - and the right to dignity as contained in section 10 of the 1996 Constitution. This issue is more fully addressed below.

In order to explore more fully the ambit of the right to life, we turn to the Indian experience, which provides an excellent example of a more creative interpretation of this right. Briefly, this approach involves drawing inferences from the right to life through the incorporation of the directive principles contained in the Indian Constitution ${ }^{12}$ in order to protect fundamental rights through a process known as "social justice interpretation". ${ }^{13}$ It is also interesting to note that this exercise ${ }^{14}$ was undertaken in order to restore legitimacy to the post-emergency Indian judiciary. ${ }^{15}$

In light of the above, it is submitted that one of the biggest threats to the legitimacy of the South African Constitution is the fact that victims or potential victims of violent crime feel that the Bill of Rights is being interpreted and enforced in such a manner as to protect the individual offender more than law-abiding citizens. ${ }^{16}$ Accordingly, it is submitted that the Indian position could provide useful guidelines in advancing a more activist interpretation of the right to life in order to facilitate the effective application of this right in a criminal justice context.

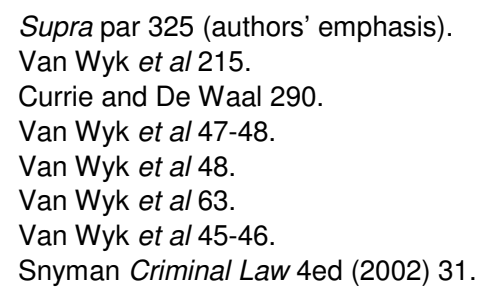




\section{THE INTERRELATIONSHIP BETWEEN THE RIGHT TO LIFE AND OTHER FUNDAMENTAL RIGHTS}

One of the foremost criticisms against drawing inferences of a "safe" life from the right to life is the argument that "freedom from violence" is already adequately protected by section 12(1)(c) of the Bill of Rights, which provides that "[e]veryone has the right to freedom and security of the person, which includes the right to be free from all forms of violence from either public or private sources". In addition, it could be argued that such an entitlement should rather form part of the right to dignity. ${ }^{17}$ The fact that these sections are relevant to the rights of everyone to be protected from violence is not disputed. It is, however, argued that the right to life must be more broadly interpreted to include within its ambit the right to a "safe" life so as to enable the holders of this right to be protected against the fear, threat and consequences of excessively violent crime.

In this regard, it would be useful to evaluate the ambit of section 12(1)(c). Is this right only infringed once violence has actually been inflicted, or does the fear and threat of potential violence also fall within its ambit? The courts have in fact interpreted section 12(1)(c) to impose positive duties on the state to protect individuals against violations of their physical integrity by other persons. ${ }^{18}$ It appears that the protection offered by this section has been limited to specific instances that have primarily resulted in the development of duties in terms of the delictual law, ${ }^{19}$ in terms of which

"[The] net of unlawfulness [is cast] wider because constitutional duties are now placed on the State to respect, protect, promote and fulfill the rights in the Bill of Rights and, in particular the right of woman to have their safety and security to protected."

Consequent consideration of these constitutional duties resulted in the extension of state liability in instances where

"the authorities knew or ought to have known at the time of the existence of a real and immediate risk to the life or physical integrity of an identified individual or individuals from the criminal acts of a third party and that they failed to take measures within the scope of their powers which, judged reasonably, might have been expected to avoid that risk."

It is submitted, however, that this protection is offered ex post facto and limited to individual protection in specific, "well-defined" circumstances. ${ }^{22}$ In addition, this contribution focuses on the protection of the right to life not only in circumstances where the risk of violent crime is real or immediate, but

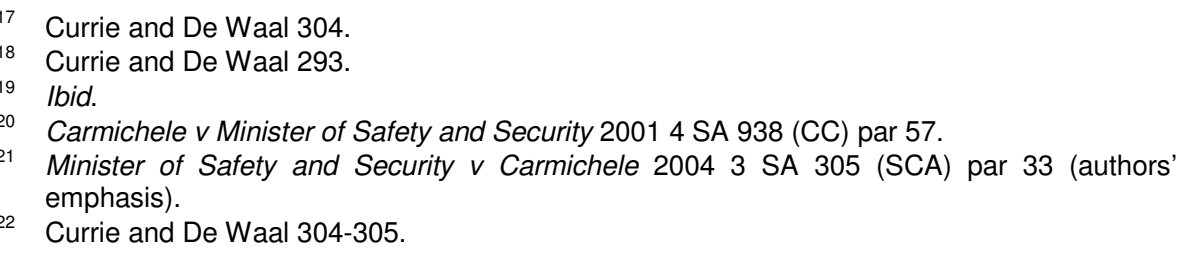


where the fear generated by the general occurrence of violent crime is of such a nature that it violates the right to a "safe" life. It is thus contended that the net should be cast even wider in order to ensure protection for all holders of this right without their physical integrity having been directly violated. In this regard, it is our contention that the courts should move away from judicial restraint and fulfill their constitutional mandate by further developing the right to life as encompassing the right to a "safe" life in situations where other specific entitlements fail to do so.

With regard to the right to dignity, it is submitted that emphasis should be placed on dignity as a value that informs the interpretation of the right to a "safe" life ${ }^{23}$ rather than interpreting the "core right to dignity" ${ }^{24}$ to include the right to a safe life. This is due to the fact that even though the right to dignity has been acknowledged as a central right, ${ }^{25}$ it is maintained that the right to life remains the antecedent right, and that - especially in light of the context of the legal question herein - the value of dignity should be seen as a component of the right to a "safe" life rather than the other way around.

\section{EMPHASIS ON THE CRIMINAL JUSTICE SYSTEM}

"Have no doubt it is fear in the land, for what can men do when so many has grown lawless? Who can enjoy the lovely land, who can enjoy 70 years and the sun that pours down on the earth, where there is fear in the heart? Who can walk quietly in the shadow of the jacarandas, when their beauty is grown in danger? Who can lie peacefully abed, while the darkness holds some secret? What lovers can lie down sweetly under the stars, when the menace grows with the measure of their seclusion? There are voices crying what must be done, a hundred, a thousand voices."

This passage, cited by Magistrate Schoeman in a court case ${ }^{27}$ dealing with the rape of three girls from Pennington, ${ }^{28}$ depicts why it is necessary to evaluate the interpretation and the application of the right to life within the context of the criminal justice system in South Africa. Upon being questioned as to why he quoted the passage, Schoeman replied "[t]he passage from Paton's book is gripping as it is almost a mirror-image of [the fear that] is currently [experienced in] the country". ${ }^{29}$

Read in its context, the passage quoted by Schoeman illustrates the lack of protection of human rights (the right to life in particular) that occurred during the apartheid era. Can it be said that the same frustration of rights is now occurring (albeit in different forms) in a post-apartheid democracy with a supreme Constitution? ${ }^{30}$ As evidenced by numerous media reports and

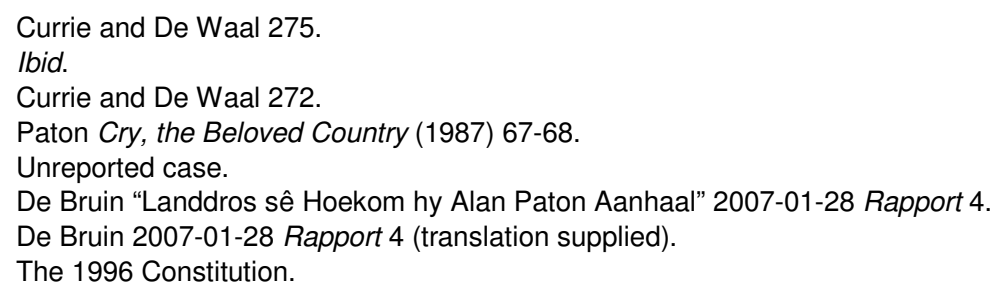


statistics $^{31}$ the majority of South Africans - which, as illustrated above, includes members of the judiciary - seem to think so.

In addition, in light of the contention that the unqualified formulation of the right to life contributes to a judicial "reluctance" to interpret and apply this right to include a certain quality of life ${ }^{32}$ it is proposed that the right to life should be re-thought and re-interpreted in order to render it more effective. This methodology excludes the analysis of the right to life in other contexts, most notably socio-economic or private law contexts. For the purposes of this dissertation it is submitted that the urgency of the factual circumstances surrounding crime in South Africa necessitates preference to be given to the development of the right to life in a criminal justice context. ${ }^{33}$

It should be kept in mind from the outset that such a re-consideration of the ambit of the right to life raises the question of the potential thereof to mandate state action in order to alleviate the circumstances that infringe the right. $^{34}$ This raises the collateral question of ascertaining the correct balance between judicial activism and deference in light of the doctrine of separation of powers, an issue to be discussed in more detail below.

Another aspect which may raise some concern is the question of the overall practicality of the proposed approach. It is submitted that the solution should operate on two levels: ideally, writ petitioners could present the question to the Constitutional Court which could interpret the right more broadly and issue a declaration that the current state of the criminal justice system infringes the right to a safe life, whereafter the state could be ordered to rectify the policy matter through, inter alia, a structural interdict. Secondly, individuals could then invoke the right to a safe life against the state by applying for remedies such as a mandamus.

31 According to SAPS statistics April to March 2005/2006, 18545 people were murdered, 54 926 women were raped, and there were 119726 reports of robbery with aggravated circumstances during this period. See http://www.saps.gov.za/statistics/reports/crimestats/ 2006/_pdf/provinces/rsa_total.pdf (accessed 2009-02-18) (hereinafter "saps.pdf/). It should be noted that these statistics only reflect rape as it was then defined. The new definition as contained in the Criminal Law (Sexual Offences and Related Matter) Amendment Act 32 of 2007 may have a very real impact on future rape statistics.

32 See fn 1 above.

33 In a victim survey conducted by the Institute for Security Studies in 2007 the respondents were asked how safe they felt walking outside in their area after dark. The responses indicate that South Africans are feeling increasingly unsafe in their respective areas, despite indications that crime levels are decreasing - the percentage of "very unsafe feeling" increased with 148\% between 1998 and 2007. Louw "Results of the 2007 National Victim's Survey" http://www.iss.co.za/dynamic/administration/file_manager/file_links/VICSURV080 508ANT.PDF?link id+24\&slink=5930\&link type12\&slink type $=13 \& \mathrm{tmpl}$ id=3http://www.iss. co.za/dynamic/administration/file_manager/file_links/VICSURV080508ANT.PDF?link_id+24 \&slink $=5930 \&$ link_type12\&slink_type $=13 \&$ tmpl_id $=3$ (accessed 2008-06-10) (hereinafter "Louw=3") 14.

34 Fedler.pdf 15-4. 


\section{EXPOSITION OF AND COMPARISON WITH THE INDIAN POSITION}

\section{Reasons for looking to India as a "source of jurisprudential inspiration"}

The fact that most judicial institutions the world over are confronted with the same difficult questions, namely the universal nature of human rights and guarantees, and the advancement of communication and information technologies, has facilitated a "growing internationalisation" of the judiciary where judges increasingly consult international and foreign sources to interpret domestic human rights provisions. ${ }^{35}$ In this regard, section $39(1)$ of the Constitution provides that:

"When interpreting the Bill of Rights, a court, tribunal or forum -

(a) must promote the values that underlie an open and democratic society based on human dignity, equality and freedom;

(b) must consider international law; and

(c) may consider foreign law."36

This section does not constitute a requirement but an authorisation for comparative interpretation. ${ }^{37}$ As such, foreign jurisdictions are more likely to be consulted in areas where there is, as yet, no established "conventional wisdom" regarding the interpretation of fundamental human rights. ${ }^{38}$ Although it is submitted that the interpretation of the right to life is an area lacking in domestic "conventional wisdom", it should also be noted that such an importation of law should not occur without adequate consideration of the context in which it is being applied. ${ }^{39}$

It should be noted that both India and South Africa have strong ties with the British tradition - India in fact continues to apply certain parts of English law after gaining independence. ${ }^{40}$ Most importantly, however, the constitutions of both India and South Africa guarantee fundamental human rights that are increasingly being interpreted and enforced. ${ }^{41}$ As such, the preambles of both constitutions envisage the improvement of the quality of life of all citizens, an ideal which is enabled by including concepts such as "appropriate relief", jurisdiction and a wide interpretation of locus standi in both documents. ${ }^{42}$ Of specific interest in this regard is the possibility of

35 Govindjee "Lessons for South African Social Assistance Law from India: Part 1 - The Ties that Bind: The Indian Constitution and Reasons for Comparing South Africa with India" 2005 Obiter 575-576.

36 Authors' emphasis.

37 Du Plessis Re-Interpretation of Statutes (2002) 273.

38 Ibid.

39 Govindjee 2005 Obiter 576.

40 Ibid.

41 Ibid.

42 Ibid. 
evaluating and applying India's "project of public interest law". ${ }^{43}$ As discussed in more detail below, the purpose of public interest litigation is to make social justice readily available. ${ }^{44}$ In order to achieve this, the Indian courts are exceptionally flexible on issues of locus standi and have developed a concept which has been called "citizen standing" ${ }^{45}$ In terms of this approach, wherever a person whose fundamental rights have been infringed is unable to approach the court due to reasons related to social or economic inabilities, any other bona fide person may institute an action in order to "promote and vindicate public interest." $\mathrm{A}$ A similar approach is enabled in South Africa by our broad standing provision in section 38 which reads as follows: ${ }^{47}$

"Anyone listed in this section has the right to approach a competent court, alleging that a Right in the Bill of Rights has been infringed or threatened, and the court may grant appropriate relief, including a declaration of rights. The persons who may approach a court are:

(a) Anyone acting in their own interest;

(b) anyone acting on behalf of another person who cannot act in their own name;

(c) anyone acting as a member of, or in the interest of, a group or class of persons;

(d) anyone acting in the public interest; and

(e) an association acting in the interest of its members."

It has been held that the category of persons "acting in the public interest" is the most problematic of the section 38 categories, as an applicant must show that he or she is acting in the public interest and that the public has a "sufficient interest" in the remedy that is sought. ${ }^{48}$

Despite inevitable differences between the Indian and South African legal systems, ${ }^{49}$ members of the judiciary have recognised ${ }^{50}$ the important role India could play as a source of reference. Justice Albie Sachs, for example, supports this contention that the Indian Supreme Court should be considered as a "source of jurisprudential inspiration" as follows:

"We look to the Indian Supreme Court which had a brilliant period of judicial activism when a certain section of the Indian intelligentsia felt let down by parliament. They were demoralized by the failure of parliament to fulfill the promise of the constitution, by the corruption of government, by the authoritarian rule that was practiced so often at that time. Some of the judges felt they must do something to rescue the promise of the constitution, and through a very active and ingenious interpretation bringing different clauses together they gave millions of people the chance to feel 'we are people in our country, we have constitutional rights, we can approach the courts'... The

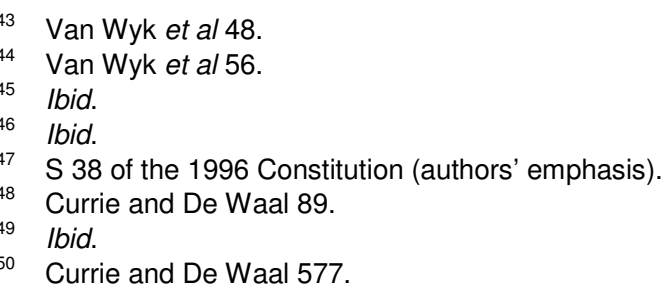


right to life is not simply the right not to be killed, it is the right to quality of life ..."

Members of the executive have also observed the close ties that exist between India and South Africa as illustrated by the following quote from former President Thabo Mbeki in the 3rd Alfred Nzo Memorial Lecture to the Indian Council of World Affairs: ${ }^{51}$

"Of importance is the fact that since the independence of India, we as South Africans have been blessed to have as our ally, this country that assumed the mantle of a champion of our liberation and democracy. Through the struggles that we waged together, today South Africa has joined the community of free nations. Undoubtedly, this has been possible because of the efforts of the people of this great nation. At the same time; there are bigger challenges that are facing the people of India, the people of South Africa and the rest of the world."

One of the "bigger challenges" South Africa is undoubtedly facing today is the negation of the very essence of the right to life brought about by the constant threat of excessively violent crime. As a result, the concepts of human rights (and the right to life in particular) run the risk of becoming a mere ritualistic ideology ${ }^{52}$ in the eyes of the public, resulting in a loss of faith in and legitimacy surrounding the Bill of Rights. As will be illustrated in more detail below, the Indian judiciary experienced a similar legitimacy crisis which was tempered by the advent of a period of judicial activism. Accordingly, it is submitted that a solution may be found in the creative and activist interpretation of this right by South Africa's "strategic partner in all seasons", ${ }^{53}$ the Indian judiciary.

\section{Judicial activism under the Indian Constitution}

\section{Introduction}

Before evaluating the structure of the Indian Constitution and the substantive interpretation of the right to life that was undertaken within that structure, an evaluation of judicial activism - the jurisprudential method that facilitated the transformation of the Indian legal system ${ }^{54}$ - is necessary. In this context, the term "judicial activism" can be defined as follows: ${ }^{.5}$

"Every proceedin[g] before the Court must reflect judicial initiative, involvement, resourcefulness [and] concern which can be packed up in one word namely, the "judicial activism" - the moving spirit of justice. The source of this judicial activism is the crusading spirit of the concerned

51 "India and South Africa: Strategic Partners for All Seasons" http://www.thepresidency.gov.za/show.asp?type=sp\&include=president/sp/2003/tm1016.htm/ (accessed 2008-03-10) (hereinafter "Strategicpartners.htm/").

52 Snyman 27.

53 Ibid.

54 Van Wyk et al 46.

55 Basu Law Relating to Protection of Human Rights Under the Indian Constitution and Allied Laws (2004) 595. 
Judge/Magistrate in delivering the substantial and speedy justice which we would like to term ... as 'Judicial Crusadism'."

As mentioned, the activist role of the Indian judiciary ${ }^{56}$ must be evaluated with due regard to the proper historical setting, namely that the transformation of the judicial system that was necessary to restore the legitimacy of the Indian Supreme Court after the declaration of a State of Emergency in India on 26 June $1975 .{ }^{57}$ The factors that led up to this declaration primarily consisted of political confrontations ${ }^{58}$ regarding poverty, inequality and proprietary rights. ${ }^{59}$ Consequently, the first twenty-five years of constitutionalism in India were characterised by a struggle between the legislature and the judiciary regarding property rights - a struggle that involved a series of judicial decisions invalidating parliamentary legislation that endeavored to bring about social change, only to be met by constitutional amendments to overrule such judgments. ${ }^{60}$ As a result, the Indian Supreme Court grew considerably unpopular and the concept of judicial review was considered so dispensable that the legislature even considered doing away with the concept of independent judicial review altogether. ${ }^{61}$

These political struggles culminated in the declaration of a state of emergency in $1975{ }^{62}$ during which the legitimacy of the judiciary reached an ultimate low point. ${ }^{63}$ The end of the emergency was brought about by the democratic election of a coalition government that envisaged a reaffirmation of citizen rights, the rule of law, and ultimately, the abolition of constitutional property rights. ${ }^{64}$

It was at this crucial point that the Indian judiciary realised that a deliberate effort had to be made to restore faith in the institution of judicial review and the rule of law. ${ }^{65}$ The avenue decided upon involved the adoption of an activist role in the protection of fundamental rights, especially the rights of the marginalised, an advent in part necessitated by the new government's abolition of property rights. ${ }^{66}$

The justification for the transformation of the judicial system was envisaged as follows in People's Union for Democratic Rights $v$ Union of India: ${ }^{67}$

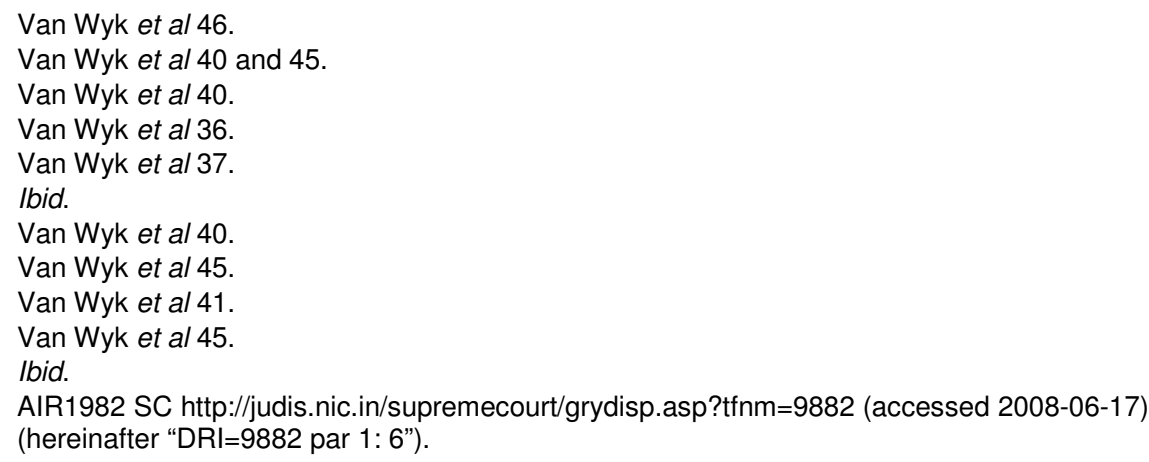


"The time has now come that the courts must become the courts for the poor and struggling masses of this country. They must shed their character as upholders of the established order and the status quo. They must be sensitized to the need of doing justice to the large masses of people to whom justice has been denied by a cruel and heartless society for generations. The realisation must come to them that social justice is the signature tune of our Constitution and it is their solemn duty under the constitution to enforce the basic human rights of the poor and vulnerable sections of the community and actively help in the realisation of the constitutional goals. This new change has to come if the judicial system is to become an instrument of social justice, for without it, it cannot survive for long."

The situation in essence required an activist judicial response ${ }^{68}$ consisting of a creative approach which has been called "social justice interpretation". ${ }^{69}$ This approach involves the "reading in" of unenforceable socio-economic rights as forming part of an expanded interpretation of the fundamental and enforceable right to life. ${ }^{70}$ In doing so, the court succeeded in re-establishing itself as a legitimate institution and "protector of the rights of the poor and underprivileged" rather than "a sentinel of the interests of the propertied classes". ${ }^{71}$ Two problems inherent in such an activist approach, the issue of separation of powers and enforcement of orders, are discussed in the next section.

\section{Separation of powers and judicial restraint}

If one considers the implications of judicial activism infused with the concept of public interest litigation as discussed, it becomes clear that this movement has inevitably involved the Indian courts in the exercise of powers which are traditionally considered to be the domain of the other branches of state. ${ }^{72}$ The functions of the Indian courts in light of the doctrine have been described as follows: ${ }^{73}$

"No one may speak for the parliament and Parliament is never before the court. After Parliament has said what it intended to say, only the Court may say what the Parliament meant to say. None else ... The executive Government may place before the Court their understanding of what Parliament has said or intended to say or what they think was Parliament's object and all the facts and circumstances which in their view led to the legislation. When they do so, they do not speak for parliament ... Validity of legislation is not to be judged merely by affidavits filed on behalf of the State, but by all the relevant circumstances which the court may ultimately find and more especially by what may be gathered from what the Legislature has itself said."

This illustrates a trend of the "post-emergency" judiciary to be especially mindful of not invading the domain of the legislature by, for example,

\footnotetext{
Van Wyk et al 46

Van Wyk et al 47.

Govindjee 2005 Obiter 578.

Van Wyk et al 45.

Van Wyk et al 58.

Basu 595.
} 
ordering the passing of legislation re-allocating state resources. ${ }^{74}$ The courts have, however, been far more willing to encroach upon the traditional domain of the executive authorities or administration. ${ }^{75}$ This phenomenon involves the court taking control of the administration of the issue under review from the executive by primarily ordering a series of interim orders to monitor the rectification of breaches of fundamental rights. ${ }^{76}$ This process has been labeled the "creeping jurisdiction" of the Indian Supreme Court in public interest cases and has, as could be expected, attracted staunch criticism from conservative corners as being an infringement of the doctrine of separation of powers. However, it is submitted that the trend of the courts to make the executive the focus of efforts to regulate the exercise of state power through judicial review ${ }^{77}$ should once again be considered in the light of Indian constitutional history. The Indian administration has always been dominated by various privileged groups endowed with great wealth and political power. ${ }^{78}$ As such, numerous legislative attempts to change and better the existing social and economic status quo have been thwarted by the bureaucracy, ${ }^{79}$ a state of affairs which the Indian courts have attempted to rectify by focusing its powers of judicial review on the executive.

However, in order to ensure the success and legitimacy of such judicial activism, the Indian courts have also accepted the limitations of their powers in public interest litigation. The court has neither the resources nor the expertise to take over the administration of every branch of the executive that has been targeted, ${ }^{80}$ especially in light of the doctrine of separation of powers. Any such acceptation, however, need not undermine the existence or importance of judicial activism in public interest matters. ${ }^{81}$ The importance of judicial intervention to safeguard fundamental rights, even at the cost of encroaching upon traditional executive powers, was described in Peoples' Union for Democratic Rights v Union of India: ${ }^{2}$

"The only solution of making civil and political rights meaningful to these large sections of society would be to remake the material conditions and restructure the social and economic order so that they may be able to realise the economic, social and cultural rights. Of course, the task of restructuring the social and economic order so that the social and economic right become a meaningful reality for the poor and lowly sections of the community is one which legitimately belongs to the legislature and the executive but mere initiation of social and economic rescue programmes by the executive and the legislature would not be enough and it is only through multi-dimensional strategies including public interest litigation that these social and economic rescue programmes can be made effective."

\footnotetext{
Van Wyk et al 58.

Ibid.

Ibid.

Van Wyk et al 59.

Ibid.

Van Wyk et al 58-59.

Van Wyk et al 58.

Van Wyk et al 59.

DRI=9882 par 1:3.
} 
It should be noted here that the emphasis does not fall on the (re)allocation of resources as decided upon by the legislature, but the actual implementation of those resources by the executive. Consequently, in order to make executive initiatives effective in light of the protection of fundamental human rights, the Indian courts have ultimately attempted to strike a balance between judicial activism and the doctrine of judicial restraint, which can be explained as follows: ${ }^{.3}$

"Judicial restraint and discipline are as necessary to the orderly administration of justice as they are to the effectiveness of the army. The duty of restraint, this humility of function should be the constant theme of our Judges. This quality in decision making is as much necessary for judges to command respect as to protect the independence of the judiciary. Respect to those who come before the Court as well as to other co-ordinate branches of the State, the executive and the legislature. There must be mutual respect. When these qualities fail, or when the litigant and public believe that the Judge has failed in these qualities, it will neither be good for the judge nor the judicial process."

It appears that the crucial lesson to be drawn from post-emergency judicial activism in light of the doctrine of separation of powers is that a balance should be maintained between judicial interpretation and the exercise of due respect for executive powers. ${ }^{84}$ Although the Indian courts have focused their efforts on the realisation of socio-economic rights, a similar approach can be endorsed and applied to assist the South African judiciary with the interpretation of the right to life in a criminal justice context and in their review of executive initiatives dealing with crime and related matters.

\section{The enforcement of orders}

Another issue deserving attention in light of the tension between separation of powers and judicial activism is the problem of enforcement of court orders. ${ }^{85}$ A significant aspect of the movement of judicial activism in India is the fact that it ultimately extended to cases requiring positive state action, ${ }^{86}$ an extension which raised additional difficulties regarding remedies imposing positive obligations on state authority and the enforcement thereof. One can summarise the Indian approach as being quick to offer extensive relief in temporary or preliminary orders and then issuing final orders in the form of a directive, together with detailed guidelines, to the state authorities who allegedly abused their duties to establish a prescribed system available to all citizens. ${ }^{87}$ Initially, it was thought that the problem of enforcement can be subverted by the appointment of commissions to monitor compliance, ${ }^{88}$ but it was soon revealed that this time-consuming process also had its limitations regarding effectiveness and exact enforcement. In this regard, the judges

\footnotetext{
Basu 597

Van Wyk et al 62-63.

Van Wyk et al 59.

Govindjee 2005 Obiter 590.

Van Wyk et al 56-57.

Van Wyk et al 59.
} 
had to accept the limitations of their powers over executive matters ${ }^{89}$ and to resign themselves to the fact that their orders could not always be effectively enforced: ${ }^{90}$

"It is obvious that what has been done has the effect of subverting the authority of this court ... [and] we cannot do anything about it ... [but] start the process all over again and commence giving directions for the improvement of living conditions on the new building."

In some instances the Indian Supreme Court deferred from issuing directives, opting rather to propose guidelines in a counter-affidavit, ${ }^{92}$ or leaving the matter to the initiative of the executive and legislature after drawing attention to a matter of public interest or need, and proposing an acceptable course of action to rectify the situation. ${ }^{93}$ The court has, on occasion, described the dilemma of requiring action from the implementers of the law as follows: ${ }^{94}$

"This court has a constitutional duty to protect the fundamental rights of Indian citizens. What happens when violators and/or abettors of the violations are those, who have been entrusted by law with a duty to protect these rights?

The task becomes difficult and also requires urgent intervention so that the rule of law is preserved and people may not lose faith in it finding violations at the hands of supposed implementers. The problem is not the absence of law, but of its implementation ... Despite [the difficulty of implementation] this court cannot remain a mute spectator when the violations also affect the environment and healthy living of law-abiders" The enormity of the problem, which, to a great extent, is the doing of the authorities themselves, does not mean that a beginning should not be made to set things right ..."

This illustrates that the court recognised the danger(s) of resorting to judicial activism, but nevertheless decided that the upholding of fundamental rights under a supreme constitution takes preference. As such, the court duly noted the difficulty of implementation in the light of the doctrine of separation of powers, but then reached the conclusion that constitutional supremacy, as informed by the rule of law, required judicial intervention in some instances. This led to the realisation that a balance should once again be struck: this time between the reality of the limits of their power over the enforcement of their orders on the one hand, and the need not to undermine the importance of public interest litigation ${ }^{95}$ on the other. In addition, there are indications that the restored legitimacy of the Indian Court has inspired the executive authorities to be more responsive to socio-economic needs, ${ }^{96}$ even when the court has failed to impose a direct sanction. In effect, few Indian authorities have recently shown a blatant disregard for an order of the

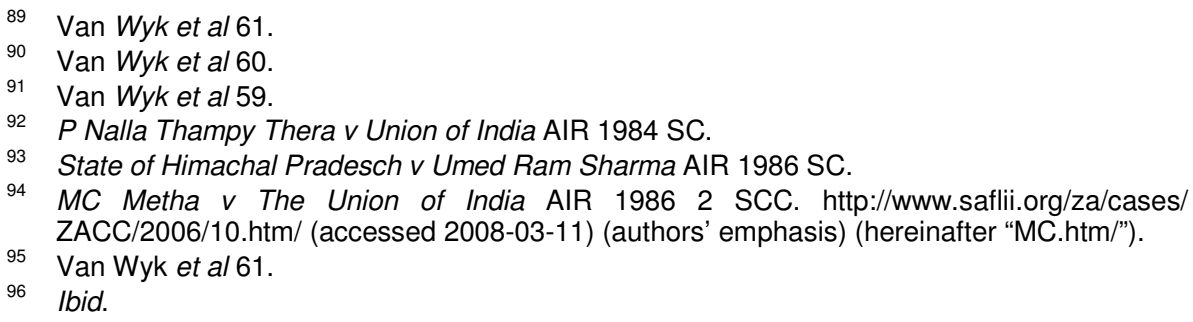


now popular Supreme Court. ${ }^{97}$ This phenomenon may be explained by the following description of the concept of public interest litigation and its purpose: ${ }^{98}$

"Public interest litigation, as we conceive it, is essentially a co-operative or collaborative effort on the part of the petitioner, the state or public authority and the court to secure the observance of the constitutional or legal rights, benefits and privileges conferred upon the vulnerable sections of the community and to reach social justice to them. The state or public authority against whom public interest litigation is brought should be as much interested in ensuring basic human rights, constitutional as well as legal, to those who are in a socially and economically disadvantaged position, as the petitioner, who brings the public interest litigation before the court."

\section{The value of the Indian approach}

The exposition of the Indian position above serves to illustrate some crucial lessons for South African courts. ${ }^{99}$ It is submitted that our courts must also reassert their institutional independence and must continue to scrutinise legislative and executive activities for unconstitutional aspects. ${ }^{100}$ Perhaps, however, the greatest lesson to be learned from the Indian experience lies in the fact that such "confrontations" with the executive and legislature should not be avoided altogether, but simply approached with due care. ${ }^{101}$ After all, if the rule of law is to enjoy legitimacy, our judiciary would have to ensure that any constitutional disputes are resolved with the necessary sensitivity and creativity. ${ }^{102}$

It should be noted that section 11 of the South African Constitution, which is formulated as unqualified and in the affirmative, ${ }^{103}$ is far more permissive than its Indian counterpart, which increases the plausibility of applying a "thicker" conception of the right to life. ${ }^{104}$ It is proposed that the right to life may be interpreted differently by "reading down" the right in light of other relevant provisions in the absence of "directive principles" employed by the Indian judiciary. The fact that the Indian judiciary arrived at an active interpretation on the basis of the factual basis of socio-economic disparity in India, ${ }^{105}$ opens the door for South African courts to draw similar inferences from the right to life in light of the factual reality of the occurrence of violent crime in South Africa.

\footnotetext{
Van Wyk et al 60-61.

DRI=9882 par $1: 4$.

Van Wyk et al 63.

Van Wyk et al 62.

Van Wyk et al 62.

Ibid (authors' emphasis)

Fedler.pdf 15-1.

Fedler.pdf 15-2.

Ibid.
} 


\section{THE QUESTION OF CONSTITUTIONAL VALUES}

"With the entrenchment of the Bill of Fundamental Rights and Freedoms in a supreme Constitution, ... [it is] imperative for courts to develop the fundamental rights in terms of a cohesive set of values, ideal to an open and democratic society. To this end, common values of human rights protection the world over and foreign precedent may be instructive."

If the right to life, as informed by human dignity, is to guarantee more than mere animal existence, ${ }^{107}$ it should be interpreted as the right to a dignified life free from the fear of excessively violent crime in order to realise more actively the values of dignity and ubuntu that underlie our Constitution. This implication is strengthened by the visions and aspirations contained in the Preamble and the guarantee of freedom from violence as contained in section 12(1)(c) of the Constitution. The courts should subsequently also delineate the state's corresponding duty to uphold such a right to a "safe" life in light of these specific values and provisions. This approach is akin to what may be termed "activist" constitutional interpretation ${ }^{108}$ and could be seen as a response to the critique that mere "lip service" is paid to fundamental rights and that they yield but hollow promises disguised in an empty rhetoric of rights. ${ }^{109}$ It is our contention that courts should actively and positively promote and strengthen fundamental rights and values by ensuring that the state meets its positive obligations with regard to the protection of the rights of the marginalised and disadvantaged, including potential victims of violent crime. ${ }^{110}$

\section{RECOMMENDATIONS}

\section{Procedural stage}

With regard to standing, it has already been mentioned that the appropriate avenue is section 38 (d) of the Constitution, which effectively grants standing to anyone acting "in the public interest". Thus it is envisaged that a person or group of persons should approach the Constitutional Court alleging that the public's right to life as contained in section 11 of the Constitution is being infringed by the failed criminal prevention strategies, programmes and policies of the state. ${ }^{111}$

Such allegations could be contained in a writ petition akin to the Indian examples discussed above, and the petitioner/s should indicate that he/she

\footnotetext{
S v Makwanyane supra par $498 \mathrm{H}-\mathrm{I}$.

S v Makwanyane supra par 326.

108 Botha Statutory Interpretation: An Introduction for Students 4ed (2005) 145.

109 Ibid.

110 lbid.

111 S 38 of the 1996 Constitution.
} 
or they is or are acting in the public interest and that the public has a sufficient interest in the requested remedy. ${ }^{112}$

With regard to jurisdiction, the writ petitioners should firstly rely on section 167(6)(a) of the Constitution and apply for leave to bring this matter directly to the Constitutional Court in the interests of justice. It is envisaged that, should this avenue fail, an order of confirmation by the Constitutional Court would in any event follow should the petition be brought to a lower court in light of section 167(5) of the Constitution, which provides that

"[T]he Constitutional Court makes the final decision whether an Act of Parliament, a provincial Act or conduct of the President is constitutional, and must confirm any order of invalidity made by the Supreme Court of Appeal, a

High Court, or a court of similar status, before that order has any force."

With regard to the procedural issue of ripeness it should be argued, if necessary, that the urgency of the criminal justice crisis system in South Africa, and the absence of ordinary legal relief in this regard, preclude the possibility that this constitutional issue can be dealt with more conveniently at a later stage.

In their application the petitioner/s should allege, in light of sections 2; $7(2), 8(1), 165(2)$ and 273 of the Constitution, that the right to life should be delineated as the right to a "safe" life, and that the duties of the state regarding executive policies and programmes for crime prevention, deterrence and sanctioning should be developed in such a way as to uphold and protect such a right more effectively. In their application, the petitioner/s must present the court with sufficient statistical and other relevant factual information in order to enable the court to make an informed decision. ${ }^{113}$ The question as to appropriate relief is discussed in more detail below.

\section{Substantive stage}

This stage of the proceedings involves the interpretation of the right to life and the delineation of the corresponding duties of the state in a criminal justice context. It is herein argued that the right to a "safe" life (free from the threat and fear of excessively violent crime) should be inferred from the right to life and that the state's duties to uphold such a right should be delineated mutatis mutandis before granting the appropriate relief.

The first step would be to "read down" the right to life ${ }^{114}$ in light of section $12(1)(c)$ (the right to freedom and security of the person) and section 10 (the right to dignity) in order to recognise the right to a "safe" life. Thus, akin to the Indian position where inferences were drawn from the right to life by reading directive principles into the right, here the inference of the right to a

12 Currie and De Waal 89.

113 See the reasoning in Government of the Republic of South Africa v Grootboom 200011 BCLR 1169 (CC) par 33.

114 Scott and Alston "Adjudicating Constitutional Priorities in a Transnational Context: A Comment on Soobramoney's Legacy and Grootboom's Promise" 2000 SAJHR 207233. 
"safe" life will be drawn by delineating its scope of application and strengthening the implication of the right through reading its content down as against the other mentioned provisions. Furthermore, the right to life should be contextualised in light of the Preamble of the 1996 Constitution which envisages the improvement of the quality of life and the freeing of potential of every person.

Secondly, the value of dignity should guide the interpretation process. It should be made clear that the recognition of the right to "safe" life would require that every person be treated as equally worthy of respect and concern. ${ }^{115}$ In this regard it is submitted that the fear of excessively violent crime substantially diminishes the potential of persons to live dignified lives.

Lastly, as ubuntu is closely related to dignity, and denotes a system of reciprocal rights and duties, ${ }^{116}$ this constitutional value could also be used to inform the state's duty to preserve, protect and uphold the right to a "safe" life. This should be done in a principled manner in order to inform the "constitutional vision of a caring [and safe] society." ${ }^{117}$ Furthermore, ubuntu could be utilised as part of a "jurisprudence of care" in order to promote the rights of the vulnerable, including victims and potential victims of crime. In this way it could be argued that recognition of the right to a "safe" life would create a just and caring society that would lead to the realisation of ubuntu as a workable constitutional norm. It is submitted that only once the right to a "safe" life is recognised will there be any "possibility of a better future" as conceived by ubuntu. ${ }^{118}$

The next inquiry would involve an investigation into whether the alleged policies and/or programmes of the state actually violate this right to a "safe" life. ${ }^{119}$ In light of the statistical information available, it could be argued convincingly that the effects of the relevant criminal justice programmes are not reasonable $e^{120}$ in light of the factual circumstances and that this amounts to a violation of the right to a "safe" life.

\section{Appropriate relief}

With regard to the question of the appropriate remedy, regards should firstly be had to section 38 of the 1996 Constitution, which provides that

"Anyone listed in this section has the right to approach a competent court, alleging that a right in the Bill of Rights has been infringed or threatened, and the court may grant appropriate relief, including a declaration of rights ..."

${ }_{115}$ Currie and De Waal 273-274.

16 Khosa v Minister of Social Development 20046 SA 505 (CC) par 163.

117 Bohler-Muller "Some Thoughts on the Ubuntu Jurisprudence of the Constitutional Court" 2007 Obiter 590593.

118 Bohler-Muller "Beyond Legal Metanarratives: The Interrelationship between Storytelling, Ubuntu and Care" 2007 18:1 Stell LR 133134.

119 Currie and De Waal 146.

120 See reasoning in Government of the Republic of South Africa v Grootboom supra par 33.

121 Authors' emphasis. 


\section{Section 172(1) further provides that}

"When deciding a constitutional matter within its power, a court -

(a) must declare that any law or conduct that is inconsistent with the Constitution is invalid to the extent of the inconsistency; and

(b) may make any order that is just or equitable, including -

(i) an order limiting the retrospective effect of the declaration of invalidity; and

(ii) an order suspending the declaration of invalidity for any period and on any conditions, to allow the competent authority to correct the defect

In terms of section 38 (d) the applicants must show that the public has a sufficient interest in the requested remedy. In light of both the urgency of the recognition of the right to a "safe" life, and the degree of executive discretion regarding the formulation and implementation of criminal justice policies regarding the control and prevention of crime, it is submitted that "appropriate relief" in this instance would be similar to the relief offered by the Constitutional Court in the Grootboom and TAC cases.

In the latter cases the Constitutional Court did not opt for mandatory relief in the form of structural interdicts as the High Courts did, but rather opted for the less intrusive remedy of a declaration of rights in terms section $38 .{ }^{122} \mathrm{~A}$ peculiar observation, however, is that these declaratory orders were formulated in such a way that they amounted to declarations of invalidity in terms of section 172(1)(a). ${ }^{123}$ For example, the order in $T A C^{124}$ firstly declared that sections 27(1) and (2) require the government to devise and implement a comprehensive programme to combat mother-to-child transmission of HIV and that this programme (which should be realised progressively within available resources) should, inter alia, include reasonable measures for counselling, testing, and appropriate treatment. ${ }^{125}$ The second part of the order declared that the current policy of government fell short of the stipulated requirements in that it restricted the prescription of Nevirapine and availability of counsellors to research and training sites. ${ }^{126}$ The final segment of the order consisted of a number of "injunctions" removing the restrictions regarding the use of Neviropene and provision of counsellors. ${ }^{127}$

It is submitted that similar relief should be granted in cases dealing with the infringement of the right to a "safe" life. The court could declare - on the basis of sufficient statistical information placed before it - that current government policies/programmes fail to uphold and protect the right to life as reformulated. This declaration could then be coupled with a supervisory

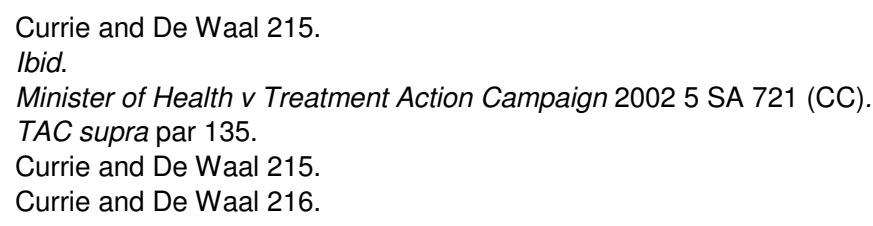


order appointing the court or some other appropriate forum as overseer of the required reformations, which should preferably take place within in a reasonable period of time. Another avenue, as is evident from Indian jurisprudence, is to provide guidelines as opposed to concrete directives, ${ }^{128}$ similar to the "injunctions" ordered in TAC.

It is envisaged that, once the declaratory (or similar) order has been issued by the Constitutional Court, the door would be opened for the granting of effective remedies on an individual scale. A practical example would be the obtaining of a mandamus from a local division directing the local authorities to take the required steps to ensure (for instance) more visible policing in a crime-infested residential area.

\section{CONCLUSION}

It can be said that there are obvious lessons to be drawn from our Indian counterparts regarding a creative approach to constitutional review. ${ }^{129}$ It is also interesting to note that this creative approach has revolved around the fundamental right to life contained in the Indian Constitution. Perhaps this is the crucial lesson for the South African judiciary: the fact that the right to life, as the antecedent human right, should be fully developed as it offers, in all probability, the strongest and most universal protection regarding aspects relating to a certain quality of life.

The Indian judiciary made a conscious decision to adopt an activist role in the protection of citizens' rights through the drawing of inferences from the right to life. It is submitted herein that the South African judiciary should similarly adopt a more "activist" approach in order to recognise what we have termed the right to a "safe" life.

It is envisaged that, once the abovementioned approach has been adopted, the South African judiciary would be one step closer to fulfilling its constitutional mandate as independent and impartial protector of fundamental rights. In the words of Justice Emeritus Ackermann,

"[U]nless one wishes to eviscerate the constitutional state at the outset, the interpretation, enforcement and protection of its constitution cannot be entrusted to either the executive or the legislature. This leaves only the judiciary to perform this duty ... The widespread assaults on human dignity by organized power groups of various kinds, including bodies elected - in some way or another - into power, [have] been a lamentable and tragic feature of humanity's lack of progress. A fully constitutionalised, human rights centered democracy, may not be sufficient to halt this chronic onslaught, but it is our only hope. Likewise an independent judiciary, as ultimate guardian of the Constitution, may not always be sufficient, but, once again, it is our only hope.

Van Wyk et al 59

129 Van Wyk et al 63.

130 Ackermann "Opening Remarks on the Conference Theme" in Klaaren (ed) A Delicate Balance: The Place of the Judiciary in a Constitutional Democracy (2006) 8 and 9 (authors' emphasis). 
Is the recognition of the right to a safe life the best way to protect bearers of this right from continuous onslaughts on their safety and dignity from the effects of the inordinately high occurrence of excessively violent crime in South Africa? It is our submission that it may, indeed, be our only hope ... 